\title{
SAMPAIO, Cláudia R. Outro nome para a solidão. Lisboa: Douda Correria, 2018.
}

Adriane Figueira Batista

Universidade de São Paulo (USP), São Paulo, São Paulo / Brasil

adriane.figueira@hotmail.com

Em cada homem moderno há um neurasténico que tem que trabalhar.

Fernando Pessoa

Recebido em: 21 de junho de 2019.

Aprovado em: 26 de junho de 2019.

Cláudia R. Sampaio é uma poeta e pintora portuguesa com cinco livros publicados em seu país: Os dias da corja (Do lado esquerdo 2014), A primeira urina da manhã (Douda Correria - 2015), Ver no escuro (2016 - Tinta-da-China), 1025 mg (2017 - Douda Correria) e o último publicado em dezembro de 2018 pela Douda Correria, intitulado Outro nome para a solidão, que será aqui apresentado. Vive em Lisboa com as suas duas gatas e atualmente é artista residente da galeria Manicómio espaço de inclusão social, criação, divulgação e incentivo da arte feita por pessoas diagnosticadas com doenças mentais.

$\mathrm{Na}$ poesia portuguesa do começo do século XX, a geração de Orpheu incorporou outros modos de conceber o existir e o estar no mundo que ampliaram o poder inventivo e criaram atmosferas para refletir o 
homem, a coletividade e a escritura. A loucura foi o modo encontrado para subverter a objetividade da vida, uma recusa ao real e um profundo mergulho na subjetividade. Poetas como Fernando Pessoa, Mário SáCarneiro e Almada Negreiros experimentaram uma loucura dissimulada, porém Ângelo de Lima vivenciou a loucura legítima que é esta loucura trágica experimentada por Cláudia R. Sampaio nos dias atuais.

A poesia de Cláudia R. Sampaio ainda não foi publicada no Brasil, porém há previsão de uma edição para o segundo semestre de 2019 que reunirá os três livros publicados em Portugal pela Douda Correria: A primeira urina da manhã (2015), 1025 mg (2017) e Outro nome para a solidão (2018), sob o título "Inteira como um coice do universo".

Capa da obra com desenho de Cláudia R. Sampaio

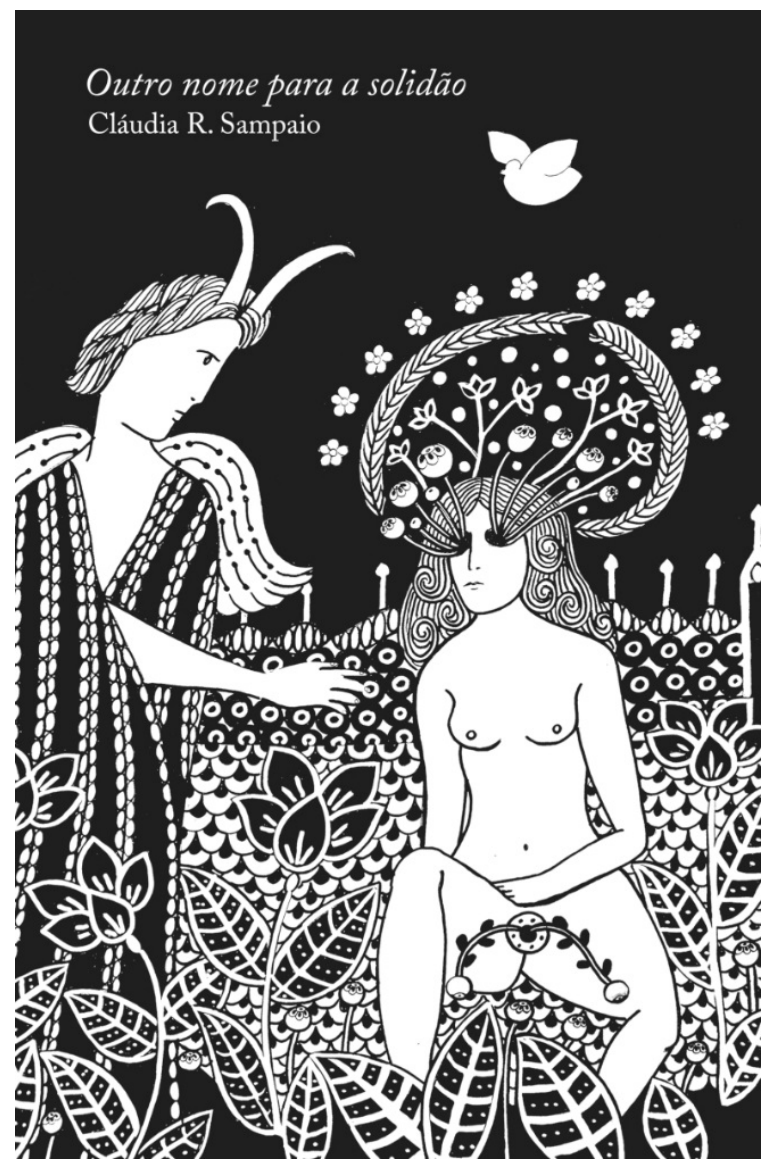


No pequeno livro Outro nome para a solidão (2018), que tem como peculiaridade a ausência de numeração das páginas, a poeta ao escancarar seus dilemas e angústias nos guia através de um labirinto criado pela persona que, ao escrever, rememora a dor e a solidão, entre sopros de lucidez até bruscas quedas protagonizadas por crises de silêncio, euforia e espanto. O livro é dividido em duas partes: Hospital e Outro nome, uma novidade já que as publicações anteriores não possuem este recurso. Ao finalizar a leitura dos poemas o leitor constata que há, pelo menos, dois tipos de solidão presentes na obra: a solidão assistida por profissionais em um centro psiquiátrico, controlada por meio de medicamentos e terapias pouco humanizadas, e a solidão cotidiana em que a relação com o outro engendra o vazio, a ausência de profundidade nas relações interpessoais e no estar no mundo:

\section{[...] Mulher nua, no quarto, desistindo da sua lírica, olhando o tecto \\ Mulher encolhida na própria sina, encontro fatal \\ Os olhos comem \\ O corpo alcança \\ A mulher ergue-se no túmulo de outra vida \\ Desaprendendo de ser gente... (SAMPAIO, 2018)}

A primeira parte do livro, intitulada Hospital, os poemas configuram um percurso de dor física insuportável, silêncio e solidão. Ao retratar momentos dentro de uma ambulância, a convivência com outros pacientes que se encontram em estados emocionais extremos e desoladores, até a calmaria do quarto quando a cabeça repousa sob o travesseiro; a mente e o corpo verbalizam todas as coisas internas, apontando para o "indizível" pronunciado, as palavras impossíveis que dançam nas folhas de papel, o vazio preenchido pela solidão absoluta. A náusea acompanha essa mulher que em sua própria metamorfose resta inquieta entre o dentro e o fora: "[...] Estou sozinha / Estou limpa / Virginal / Inteira como um coice do universo" (SAMPAIO, 2018).

A paradoxal loucura lúcida é o que a própria voz que ressoa dos versos propõe ao se autoproclamar Lúcida, assim, com maiúscula. "A obsessiva solidão cantante" como aparece na epígrafe desta obra. Os versos citados de Herberto Hélder funcionam como bússola, pois para além de uma solidão audível e visível, temos um universo interior que 
se ergue: não há nada a dizer, só o vazio e o silêncio, porém é impossível calar:

[...] Não sou mais do que aquilo que sou

Não me peçam para aderir ao vício da cobardia

Sou demasiado mortal

Lúcida

[...] Então destruirei os alicerces, serei a habitação da casa

este ar murcho há muito que desaba no meu telhado

Tenho os braços carregando os homens tolos e no topo, como um Éden alagado em mármore, todo o meu excessivo amor (SAMPAIO, 2018)

Os versos recortados do longo último poema da primeira parte da obra trazem uma mulher que arde na ânsia das coisas impossíveis, dos delírios que vertem abismos, na condição de criatura estranha, desconhecida que não deseja permanecer estática. Sem um lugar próprio, um mundo a que este ser pertença, a poeta caminha pela objetiva eternidade temporal que não se deixa abalar pelas ações do sujeito seguindo seu curso. O espectro da mulher que "morre" sentada, porém atenta às transformações - um escoar de corpos e sentimentos fragmentados, mergulhados em um excessivo amor, uma voz que desloca o olhar e o lugar de partida e de chegada:

[...] Tu não sabes

mas todos os poetas amamentam as coisas

que ninguém quer

os meus seios vão secando entre cada golpada

entre cada chupar de invisibilidade

$\mathrm{e}$, este leite que lhes dou incessantemente,

é para que as vejas também (SAMPAIO, 2018)

O que se evidencia na leitura destes versos é a impossibilidade do sujeito diante do outro, o dentro que se quer fora, uma transferência no olhar de quem percebe com maior nitidez as coisas do mundo, os mistérios e consequentemente tudo o que é incômodo. Neste "amamentar" poético de tudo o que é recusado, a poeta se ergue como resistência e seus versos transbordam a fim de reordenar utopicamente o horizonte e o alcance do olhar. 
Avançando pelas páginas finais da obra Outro nome para a solidão há versos que reforçam este mal-estar que não desaparece após a internação, não há um modo capaz de apagar o caos que acompanha a poesia e nela encontra abrigo. Na busca pelo outro nome que não seja solidão, a poeta atravessa o inferno com um olhar atento, dentro dos limites da lucidez, e, abraçada ao paradoxo da existência solitária que é a existência humana por excelência. Com as incertezas que engendraram as certezas atuais de que não há saída, porém todas as possibilidades são postas no jogo poético:

Um outro nome que não seja solidão

Um outro nome que nos distraia das nódoas,

que nos faça cair de pé como os gatos

[...] Repara como é precioso este momento de levantar o braço levar a colher à boca

dizer adeus e não voltar (SAMPAIO, 2018)

\section{Referência}

MARTINS, Fernando Cabral. (coord.). Dicionário de Fernando Pessoa e do modernismo português. São Paulo: Leya, 2010. 